190 Butlen and Jard: Urinary Cyclic AMP and Phosphate Excretions in the Rat

40. Taylor, A. T., Davis, B. B., Pawlson, G., Josimovich, J. B., Mintz, D. H.: Factors influencing the urinary excretion of $3^{\prime}-5^{\prime}$-adenosine monophosphate in humans. J. Clin. Endocr. 30, 316-324 (1970).

41. Walton, G. M., Garren, L. D.: An assay for adenosine $3^{\prime}-5^{\prime}$-cyclic monophosphate based on the association of the nucleotide with a partially purified binding protein. Biochemistry 9, 4223-4228 (1970).

Dr. S. Jard

Laboratoire de Physiologie cellulaire

Collège de France

Place M. Berthelot

Paris 5e, France

\title{
Erratum
}

\section{On the Birefringence of Rods and Cones}

\author{
R. A. Weart
}

Pflügers Arch. 329, 244-257 (1971)

The suffixes $L$ and ${ }_{p}$ in line 9 on page 246 should be interchanged.

\author{
R. A. Weale \\ Dept. of Physiological Optics \\ Institute of Ophthalmology \\ Judd Street \\ London WC1H 9QS, Great Britain
}

